\title{
Influences of SNS (Social Network Service) Uses and Musical Consumption on City Branding: A Focus on Broadway, New York and the West End, London
}

\author{
Jongwon Won ${ }^{1}$, Jong Yoon Lee ${ }^{2}$ and Jong Woo Jun ${ }^{3, *}$ \\ 1 Department of Media Communication, Soonchunhyang University, Chungnam 31538, Korea; jwon@sch.ac.kr \\ 2 Department of Photography, Visual \& Contents, Sangmyung University, Seoul 03016, Korea; \\ jongyoonlee1@smu.ac.kr \\ 3 School of Communication, Dankook University, Gyeonggi-do 16890, Korea \\ * Correspondence: jwjun@dankook.ac.kr
}

Received: 28 March 2020; Accepted: 26 April 2020; Published: 9 May 2020

check for updates

\begin{abstract}
This study explored the role the musical industry plays in creating city brand images. The results showed that younger consumers were found to have more favorable visit intentions in New York and London due to their image as musical cities. Instagram users wanted to visit New York, but Twitter users had negative visit intentions in New York. Sensation-seeking orientation toward musicals influenced visit intention in New York. Broadway familiarity was linked to visit intention. In London, only sensation-seeking orientation influenced visit intention. Uses of SNS did not influence London visit intention and West End familiarity was not related to London visit intention. These results could provide academic and managerial implications for city branding.
\end{abstract}

Keywords: musicals; city branding; SNSs; orientation; sustainable tourism

\section{Introduction}

Countries, cities and communities are competing with each other in global environments. They develop marketing strategies and aim to attract residents, tourists, international students and even immigrants [1]. The term of place branding is a macro concept and country branding, city branding, and community brand are based on micro perspectives for individual places. Cities can be one of the basic units for place branding because nobody can visit a country without visiting a specific city or local places. Community brands are too small to be independent segments of place branding. Some cities are famous domestically or internationally. In this case, a certain city has its own unique identity. Identity is a critical element to be a recognizable city among other competing cities. This problem is why cities need to strategically brand their images to draw the attention of tourists or residents. City branding includes various tools along with media advertising. However, paid communication has limitations for city branding because cities have more complex and diverse identities and propositions [2].

Brand assets include various elements such as heritage, people, companies and culture. Some cities are famous for cultural attractions. European cities are famous for their cultural images stemming from traditional equity. On the other side, artificial things can be attractive sources of city branding. For example, Florida is a famous place because of Disney World, LA because of Disney Land, New York for Broadway and European cities for classical music. Broadway and the West End are well known due to their musical industries. International tourists visit Broadway and the West End to watch original performances of musical masterpieces. However, the research investigating roles of entertainment industries on city branding is limited and so it is required to fill this academic gap. 
This study tried to explore the effects of cultural industries on city branding and proposes the research model that proposes musical and cultural content could be the main reason tourists visit these cities. Using Broadway, New York and the West End, London as research targets, these relationships are investigated. The results could provide academic implications and managerial insights for city marketers and even musical producers. Artificial industries can be used as sustainable tourism attraction because they do not destroy natural resources such as mountain, beach and natural scenery, etc. Musical industries contribute an ecofriendly, sustainable tourism.

\section{Literature Review}

\subsection{City Branding}

The concept of brands has been used when companies deal with their products or services. However, the application of brands extends to various fields, and the public sector also uses brand management as a strategy. Representative examples are place brands and country brands. The term of place branding is used when dealing with particular regions. Country brands are the ultimate goals that individual countries try to build. Cities also utilize branding strategies to build more competitive brand equity. Destination branding needs to be differentiated from general place branding because destination branding is a tourism-oriented concept [3]. A destination is an object to visit for travelers, but a place can be an object to consume for various purposes.

Images are important concepts for city branding. Lynch [4] first used the concept of city images, and classified city images into paths, edges, districts, nodes, and landmarks based on the physical characteristics of cities. Appleyard retested the results of Lynch using the city of Ciudad Guyana in Venezuela, and Nasar analyzed Knoxville and Chattanooga in Tennessee to improve the old images of the two cities [4-6]. After that, Banai [7] analyzed comparative importance among adjectives, but this study had problems with generalization because the research cities were limited to college towns. Raporport stressed the complex characteristics of cities and added social and temporal characteristics along with the physical characteristics that Lynch suggested [4].

City brand equity includes brand awareness, perceived quality, brand attitudes, and brand loyalty [8]. City image studies are based on awareness of cities, and subsequent research also used city awareness using logical backgrounds and methods [9], applications to other cities [10], and the relationship between images and behaviors [11]. The goals of city branding include attracting tourists, shoppers, and global business people [1]. The ultimate goal of city branding is to build a unique city identity [12], and the concept of a creative city was suggested to make unique brand identity competing with other cities [13]. More recently, it was found that brand attitude, trust, commitment and uniqueness were important elements influencing city branding [14].

A city's brand can be built by various tools. Traditional marketing communication could make cities more noticeable, but they are not efficient communication methods. Cities are more complicated entities that are different from general companies or organizations. Non-traditional communication tools could be alternative ways to deliver favorable images to the public, consumers and tourists [2]. Cultural and entertainment approaches are helpful to build city images and brands [14]. More specifically, cinema can also provide an effective medium to deliver city images to tourism consumers [15]. The roles of cultural festivals were also supported for the city of Suwon, the capital of Gyeonggi-do, South Korea [16].

\subsection{SNS Uses}

As mass media continues to shed its power, people obtain information from alternative sources of content. SNS is a platform that is networking people based on users' common interest, hobbies and even professional opinions. SNS is defined as "a networked platform in which participants have uniquely identifiable profiles; can publicly articulate connections; and can consume, produce, and/or interact with streams of user-generated content" [17]. YouTube has become a primary information 
channel, and Facebook and Instagram also play important roles in information distribution [18]. SNS could construct virtual communities, and users could support each other by translating certain intentions into specific behaviors, through sharing goals and challenges [19]. SNS explains that social penetration happens without face-to-face relationships through online interpersonal interactions along with self-disclosure practices [20].

Many social capital studies have been done regarding the roles of SNS uses [21,22]. SNS users show higher scores on social capital dimensions such as face-to-face interactions, number of acquaintances, and bridging capital than non-users, and male users are reported deeper loneliness than female users [21]. The amount of time that users spend on SNS could differentiate users' specific behaviors and perceptions on social capital [22]. Heavy users are more likely to share information and use application programs frequently.

Individual SNSs have different characteristics. WhatsApp is a multifaceted communication tool; Facebook is used to display the socially acceptable self; Instagram is useful for stylized self-presentation; Twitter is a channel for information; and Snapchat provides an environment for spontaneous and playful connections [23]. Instagram influences a shopper's life [24]. Twitter enhances users' news knowledge, and these Twitter effects are moderated by the need for orientation and type of news [25].

Social media provides an entertainment experience to users, and competence and autonomy directly influenced enjoyment [26]. SNS is known to provide various reviews for theme parks [27]. It is found that Twitter enhanced hard news knowledge when users have a higher need for orientation [25]. Social media also motivates collaborative information seeking when people are planning group trips [28]. Different social media provide different forms of information [29].

SNS can be used as marketing communication tools, and create consumer trust toward user-created SNS content [30]. Different types of SNS users influence SNSs marketing performance, and social surveillance and self-surveillance can be factors classifying SNS users [31]. The four types of SNS users are versatile users, self-expression users, pass-along users, and introvert users. The most noticeable role of SNSs is to be helpful for tourism organizations to make more effective decisions [32]. This can be applied to an individual tourist.

According to the literature, Facebook plays roles to illustrate city personality [33]. Social media is also effective to deliver information of festivals that a city holds to promote favorable city images [16]. This study operationally defined SNS uses as daily uses of user-generated content of musicals that are posted on YouTube, Facebook, Instagram, and Twitter. According to the previous literature, it can be hypothesized that people will have positive visit intentions when they use SNS for musical information. This study will explore the effects on New York and London, cities that are famous for their musical industries.

Hypothesis 1 (H1). SNS uses will influence city visit intentions positively.

Hypothesis 1a (H1a). SNS uses will influence New York visit intentions positively.

Hypothesis $\mathbf{1 b}(\mathbf{H 1 b})$. SNS uses will influence London visit intentions positively.

\section{Musical Orientation}

People watch musicals for various purposes and motivations. Some musical fans could have a particular orientation toward musical performance. Why people use is an important issue in performance marketing. Orientation used in marketing is defined as the propensity to do predictable behaviors [34]. Two important concepts to define orientation are motivation and value [35]. Orientation also is expressed as sustainable involvement [36]. Another key concept of orientation is modality $[35,37,38]$. People's orientation (motivation and value) is presented in a typical modality. When we think about sports, people could express orientation through emotional responses [39]. 
Others could deal with sports with social motivation [40]. Ultimately, orientation can be classified into sensation-, cognition-, and socialization-seeking orientation [41].

This study uses the concept of orientation to explain the roles of musicals in a city branding context. Originally, orientation was developed for sports events, but it is useful to understand the motivation of content users [41]. Using three orientation dimensions toward musicals, the relationship between musical orientation and visit intention in both cities are proposed.

Hypothesis 2 (H2). Musical Orientation will influence city visit intentions positively.

Hypothesis 2a (H2a). Musical Orientation will influence New York visit intentions positively.

Hypothesis $\mathbf{2 b}$ (H2b). Musical Orientation will influence London visit intentions positively.

\section{Place Familiarity}

Familiarity refers to the cognitive structure that individuals hold toward a certain product [42]. Familiarity is also said to be the complicated and refined memory structure of stimulus through repeated processes of exposure, encoding, and representation [43]. Brand familiarity means that users have professional knowledge and experiences about a certain product or brand [44]. It means that brand familiarity involves the degree of knowledge that consumers perceive [45].

The reason why familiarity is important is that familiarity could influence consumer attitudes and behavioral intention. For example, when consumers hold knowledge about products and brands, they have confidence and hold preferences and choose a certain product and brand [42]. Even when persuasion knowledge is activated, brand familiarity decreases the negative effects [46]. Consumers have more purchase intention on familiar brands than unfamiliar ones in initial purchases [47]. This relationship between brand familiarity and purchase intention is confirmed on photo service and car insurance [48]. Another case can be found in country-of-origin effects. People who are familiar with a country or a product might lead to purchasing [49]. It is also found that consumers purchase familiar products to reduce shopping time [50].

Familiarity has been dealt with in terms of the number of visits, the quantity of information, and past experiences from tourism perspectives [51]. Place familiarity is classified into experiential familiarity and informational familiarity [51,52]. This study focuses on both experiential familiarity and informational familiarity and explores the roles of familiarity on visit intentions in New York and London.

Hypothesis 3 (H3). Place familiarity will influence city visit intentions positively.

Hypothesis 3a (H3a). Broadway familiarity will influence New York visit intentions positively.

Hypothesis $3 \mathbf{b} \mathbf{( H 3 b ) . ~ P l a c e ~ f a m i l i a r i t y ~ w i l l ~ i n f l u e n c e ~ L o n d o n ~ v i s i t ~ i n t e n t i o n s ~ p o s i t i v e l y . ~}$

\section{Methodology}

The study chose New York and London as research targets because those two cities were famous for musical industries and adequate to study relationships with city branding and tourism marketing. This study used a survey research method. Using general consumers in South Korea as a research sample, the hierarchical relationships were investigated. Research samples were collected from research panels that a professional research company provides. Among respondents, people who had never watched musicals were excluded. Collected data were analyzed using hierarchical regression and the SPSS16 package was used for statistical data processing. 


\subsection{Samples}

Sampling was done in 2019, April 1 to 15. A survey questionnaire was sent to people who had the opportunity to watch musicals at least once in the past year. A total of 339 participated in the survey. The gender of respondents are equally allocated, and ages are also allocated to $20 \mathrm{~s}, 30 \mathrm{~s}, 40 \mathrm{~s}$, and $50 \mathrm{~s}$ evenly. Among them, males made up 175 (51.6\%), and females made up 164 (48.4\%). The ages of participants ranged from 20 to 59 , and the mean age was 39.8 years $(S D=10.7)$. One hundred and twelve respondents (33.0\%) visited the United States, 60 (17.7\%) visited New York, $72(21.2 \%)$ visited the United Kingdom, and 70 (20.6\%) visited London. All participants were Korean.

\subsection{Measurements}

SNS uses are measured by the sentence 'I use musical information on $(\ldots \ldots)$ ' using Facebook $(M=3.20$, S.D. $=1.66)$, Instagram $(M=3.14$, S.D. = 1.76), Twitter $(M=2.71$, S.D. $=1.65)$, and YouTube $(\mathrm{M}=3.75$, S.D. $=1.87)$. Other variables such as orientation, familiarity, and visit intention are measured as the previous literature has suggested. Orientation was measured using three different dimensions of socialization-, sensation-, and cognition-seeking orientation [41]. Socialization seeking includes 'I am often involved in conversations about musicals,' 'I like talking about musicals with people I know,' 'Watching musicals is a good opportunity to socialize,' 'Watching musicals is a good opportunity to socialize with one's friends' $(\mathrm{M}=4.10$, S.D. $=1.33$, alpha = 0.94). Sensation seeking includes, 'For me, watching musicals is a real pleasure,' 'I am always excited when I am going to watch a musical,' 'I am always enthusiastic when I think about watching musicals,' 'When I watch a musical, I sometimes feel like I am part of the musical,' 'I feel really happy when I can watch a musical' $(\mathrm{M}=4.95, \mathrm{~S} . \mathrm{D} .=1.21$, alpha $=0.95)$. Cognition seeking includes 'I consider myself as a musical expert,' 'I know very much about musicals,' 'I am really interested in any information regarding musicals' $(\mathrm{M}=3.49$, S.D. = 1.38, alpha = 0.92). Familiarity was measured by Kent \& Allen (1994) [53] with statements such as 'I am familiar with Broadway,' 'I experienced Broadway a lot,' 'I know Broadway well' (Broadway M = 3.12, S.D. $=1.39$, alpha = 0.92; West End $\mathrm{M}=2.64$, S.D. $=1.46$, alpha =0.97). Visit intention was measured using three items of 'provable,' 'likely,' 'possible' (New York M = 5.25, S.D. = 1.22, alpha = 0.92; London $\mathrm{M}=5.22$, S.D. $=1.23$, alpha $=0.93$ ). All measurement items are summated, and used as individual variables.

\section{Results}

\section{Hypotheses Testing}

Table 1 shows the results of the hypothesis test. A four-stage hierarchal regression analysis was implemented to verify the eight hypotheses. In the first stage, we tried to control demographic variables. In the second stage, we included four factors from SNS uses: Facebook, Instagram, Twitter, and YouTube. In the third stage, we included musical orientation such as socialization seeking, sensation seeking, and cognition seeking. In the final stage, we added city familiarity to verify the effect of place familiarity on visit intention.

In the first stage, we controlled demographic variables and verified that age has a direct effect on visit intention in New York. In the second stage, the model included SNS uses, and uses of Instagram were found to be effective at a limited level $(p<0.10)$. In the third stage, we included musical orientation and sensation-seeking orientation was statistically significant $(p<0.001)$. The results of the analysis showed that the third model had a higher coefficient of determination (17.2\%) than models 1 and 2. In addition, Instagram use, which had only a limited effect in model 2, showed a meaningful effect of $p<0.05$, and Twitter use, which did not have a meaningful effect in model 2 , became statistically significant in a negative way $(p<0.05)$. The final model included familiarity with Broadway. The results of the analysis showed that Broadway familiarity influenced visit intention in New York. 
Table 1. Results of hierarchal regression analysis on visit intentions of New York.

\begin{tabular}{|c|c|c|c|c|c|}
\hline DV & IV & Model 1 & Model 2 & Model 3 & Model 4 \\
\hline \multirow{10}{*}{$\begin{array}{l}\text { Visit Intention of } \\
\text { New York }\end{array}$} & GENDER & 0.012 & 0.002 & 0.054 & 0.044 \\
\hline & AGE & $-0.142 * *$ & $-0.122 *$ & $-0.110 *$ & $-0.120 *$ \\
\hline & Facebook & & 0.005 & -0.033 & -0.050 \\
\hline & Instagram & & $0.186 \#$ & $0.196^{*}$ & $0.189 *$ \\
\hline & Twitter & & -0.117 & -0.143 * & $-0.162 *$ \\
\hline & YouTube & & 0.124 & -0.001 & -0.004 \\
\hline & Social OT & & & -0.014 & -0.029 \\
\hline & Sensation OT & & & $0.390 * * *$ & $0.413^{* * *}$ \\
\hline & Cognitive OT & & & 0.013 & -0.081 \\
\hline & Broadway F & & & & $0.162 *$ \\
\hline \multicolumn{2}{|c|}{ Adjusted $\mathrm{R} 2=(\Delta \mathrm{R} 2)$} & 0.014 & $0.055(0.052)$ & $0.172(0.122)$ & $0.180(0.011)$ \\
\hline \multicolumn{2}{|c|}{$\mathrm{F}$} & $3.434 *$ & $4.267^{* * *}$ & $8.782^{* * *}$ & $8.426^{* * *}$ \\
\hline
\end{tabular}

Another four-stage hierarchal regression analysis was implemented to verify hypotheses for London visit intentions. In the first stage, we verified that age has a direct effect on visit intention in London. In the second stage, we could not find any statistically significant variables on visit intention in London. In the third stage, we found that the sensation-seeking orientation was statistically significant $(p<0.001)$. In the fourth stage, West End familiarity did not influence visit intention in London (see Table 2).

Table 2. Results of hierarchal regression analysis on visit intentions of London.

\begin{tabular}{|c|c|c|c|c|c|}
\hline DV & IV & Model 1 & Model 2 & Model 3 & Model 4 \\
\hline \multirow{10}{*}{$\begin{array}{l}\text { Visit Intention of } \\
\text { London }\end{array}$} & GENDER & 0.037 & 0.027 & 0.073 & 0.071 \\
\hline & AGE & $-0.140 *$ & -0.133 * & $-0.112 *$ & $-0.115^{*}$ \\
\hline & Facebook & & 0.032 & 0.006 & 0.004 \\
\hline & Instagram & & 0.085 & 0.102 & 0.099 \\
\hline & Twitter & & -0.031 & -0.043 & -0.049 \\
\hline & YouTube & & 0.083 & -0.034 & -0.031 \\
\hline & Social OT & & & 0.044 & 0.043 \\
\hline & Sensation OT & & & $0.343^{* * *}$ & $0.347^{* * *}$ \\
\hline & Cognitive OT & & & -0.063 & -0.078 \\
\hline & West End F & & & & 0.026 \\
\hline \multicolumn{2}{|c|}{ Adjusted $R 2=(\Delta R 2)$} & 0.015 & $0.029(0.026)$ & $0.118(0.095)$ & $0.115(0.000)$ \\
\hline \multicolumn{2}{|c|}{ F } & $3.506 *$ & $2.688 *$ & $6.018^{* * *}$ & $5.412 * * *$ \\
\hline
\end{tabular}

\section{Discussion and Conclusions}

This study explored the role of musicals on city brand images in New York and London. The findings of this study showed that younger consumers were found to have more favorable visit intentions in New York and London. Regarding the effects of SNS, Instagram positively influenced visit intention in New York, but Twitter negatively influenced visit intention in New York (H1a). We could not find significant effects of SNS on visit intention in London (H1b). Among the three 
musical orientation dimensions, sensation-seeking orientation influenced visit intention in New York (H2a) and London (H2b). Broadway familiarity positively influenced visit intention in New York (H3a), but West End familiarity was not related to London visit intention (H3b).

This study has some academic implications. It is found that musicals could be important antecedents of city branding. This result supported the roles of entertainment content on city marketing $[15,16]$. It is accepted that traditional advertising and marketing are not sufficient to build city brand equity, and cultural products of cities can be precious elements of city brand equity [2]. This study supported the proposition that the musical industry plays an important role in place and city brands. Musicals are an essential business in New York and London, and this physical element can be regarded as a part of city brand equity.

SNSs showed influences as distribution channels of musical information, and it was similar to the results found in the previous literature illustrating the effects of SNS on city branding [16,33]. It is well known that traditional media have lost their power, and SNSs seem to replace traditional media [20]. Online communication has already become the dominant way of facilitating interpersonal and mass communication. The findings of this study also support the novel roles of SNSs as information providers. The information delivered by SNSs could cultivate perceptions of travelers and lead them to behavioral intention. The more people use musical information, the more likely that they have visit intention. However, the roles of Instagram and Twitter are different. Instagram positively influenced visit intention of New York, but Twitter showed negative influences. It is because of the different characteristics of SNS. Instagram is used for self-presentation, and Twitter is used for information seeking [23]. These different characteristics might involve the influences of SNS.

Another finding is that place familiarity is linked to city branding, and it is in the same line of thoughts of the previous literature [44]. However, it is also found that the roles of Broadway and the West End influence city branding differently. Even though the West End is the birthplace of the musical, associations of musicals and London are weak compared to New York. It stems from the gap of existent brand power between New York City and London. New York has a strong background in various cultural products or content industries. New York is the center for broadcasting and advertising, along with musicals, and also is famous for financial services. On the contrary, London has limited associations as a cultural destination for Korean tourists. It is true that London has strong brand power, but this brand power is not built on musicals.

This study provides a couple of managerial implications. Cultural products can be used as tourist attractions for cities. For example, European cities are famous for classical music. Museums also can attract tourists to historical or natural exhibits. However, we could not find the role of the musical in the city brand of London. It is recommended for brand managers of London to build more strong associations with musicals performed in the West End. Broadway is a symbol of the musical that leads to images of New York, but the West End is as well known to international consumers or visitors. Branding the West End is an urgent task to utilize cultural images of a musical city. Successful case studies could give insightful implications.

Small cities also learn the managerial implications of cultural marketing for cities that do not have enough cultural resources. It is difficult to foster a cultural industry in a short period. In this case, cultural festivals can be an alternative option. A city can develop a cultural festival related to the city's image. The Edinburgh International Festival in Scotland is the representative case. The Munich Beer Festival is another successful case of cultural events. Well-made regional festivals could build favorable city images and even attract visitors to the city.

Another implication is the effect of individual SNS services. SNSs are now major marketing communication tools for companies and public organizations, but the selection of individual platforms needs to be strategically considered for cities. Instagram positively influenced visit intention to New York, but Twitter showed negative influences. This might be because Twitter lost its influence on entertainment content users. In this regard, information channels should be managed strategically to 
communicate with musical consumers regarding trips to musical cities. Particularly, media management of Instagram could be fruitful for marketing managers.

In sum, this study showed entertainment industries could be important elements of city branding. Particularly, the concept of orientation was suggested, and this study found specifically to be a motivation of musical influencing city visits. Additionally, roles of familiarity were supported academically, and effects of SNS content should be used in terms of practical strategies.

This study has a few limitations. The homophily phenomenon of the sampling issue could be mentioned because we used only musical fans. This could be an obstacle for generalizing the result of this study. In addition, we could not find antecedents influencing the city brand of London. Even though London has unique characteristics, a weak association between musicals and London is unexpected. Future research exploring significant elements influencing the brand of London is necessary. Further, other entertainment industries other than musicals need to be investigated in terms of city or place branding. This study used only Korean consumers, and future studies dealing with more generalizable international samples will be also fruitful.

Author Contributions: Conceptualization, J.W.; Methodology, J.W.J.; Data Curation, J.Y.L.; Writing Original Draft Preparation, J.Y.L.; Writing Review \& Editing, J.W.J.; Project Administration, J.W.J.; Funding Acquisition, J.W. All authors have read and agreed to the published version of the manuscript.

Funding: This research received no external funding.

Conflicts of Interest: The authors declare no conflict of interest.

\section{References}

1. Bagaeen, S.G. Brand Dubai: The Instant City; or the Instantly Recognizable City. Int. Plan. Stud. 2007, 12, 173-197. [CrossRef]

2. Jun, J.W. Impacts of Novelty of North Korean Cheerleaders and Olympic Engagement on Olympic and PyeongChang Attitudes: A Focus on Perspectives from Korean College Students. Inf. Soc. Media 2019, 20, 175-195.

3. Walmsley, D.; Young, M. Evaluative Images and Tourism: The Use of Personal Constructs to Describe the Structure of Destination Images. J. Travel Res. 1998, 36, 65-69. [CrossRef]

4. Lynch, K. The Image of the City; MIT Press: Cambridge, MA, USA, 1960.

5. Stann, E.J.; Appleyard, D. Planning a Pluralist City: Conflicting Realities in Ciudad Guayana. Hisp. Am. Hist. Rev. 1977, 57, 774. [CrossRef]

6. Nasar, J.L. The Evaluative Image of the City. J. Am. Plan. Assoc. 1990, 56, 41-53. [CrossRef]

7. Banai, R. A methodology for The Image of the City. Environ. Plan. B Plan. Des. 1999, 26, 133-144. [CrossRef]

8. Kladou, S.; Kehagias, J. Assessing destination brand equity: An integrated approach. J. Destin. Mark. Manag. 2014, 3, 2-10. [CrossRef]

9. Howard, R.B.; Chase, S.D.; Rothman, M. An analysis of four measures of cognitive maps. Environ. Des. Res. 1973, 2, 254-264.

10. Klein, H.J. Urban Core and Inner City; Brill: Leiden, The Netherlands, 1967.

11. Downs, R.M.; Stea, D. Maps in Minds: Reflections on Cognitive Mapping; Harper \& Row, Publishers: New York, NY, USA, 1977.

12. Kavaratzis, M.; Ashworth, G.J. City Branding: An Effective Assertion of Identity or A Transitory Marketing Trick? Tijdschr. Voor Econ. En Soc. Geogr. 2005, 96, 506-514. [CrossRef]

13. Landry, C. The art of city making. Aust. Plan. 2006, 43, 47. [CrossRef]

14. Kemp, E.; Childers, C.Y.; Williams, K.H. A tale of a musical city: Fostering self-brand connection among residents of Austin, Texas. Place Brand. Public Dipl. 2012, 8, 147-157. [CrossRef]

15. Chen, S.; Shih, E. City branding through cinema: The case of postcolonial Hong Kong. J. Brand Manag. 2019, 26, 505-521. [CrossRef]

16. Yoon, S.-W.; Chung, S.W. Promoting a World Heritage Site through Social Media: Suwon City's Facebook Promotion Strategy on Hwaseong Fortress (in South Korea). Sustainability 2018, 10, 2189. [CrossRef]

17. Ellison, N.; Boyd, D.M. Sociality Through Social Network Sites; Oxford University Press: Oxford, UK, 2013; pp. 1-26. 
18. Angelovska, N. Facebook Losing Users To Pinterest, Youtube And Twitter (Market Share By Region). Available online: https://www.forbes.com/sites/ninaangelovska/2019/01/07/facebook-loosing-users-topinterest-youtube-and-twitter-market-share-by-region/\#58ffab627746 (accessed on 7 January 2019).

19. De La Pena, A.; Domínguez, C.Q. Share, like and achieve: The power of facebook to reach health related goals. Int. J. Consum. Stud. 2015, 39, 495-505. [CrossRef]

20. Pennington, N. Building and Maintaining Relationships in the Digital Age: Using Social Penetration Theory to Explore Communication through Social Networking Sites. Ph.D. Thesis, University of Kansas, Lawrence, KS, USA, 2015.

21. Brandtzaeg, P.B.; Brandtzæg, P.B. Social Networking Sites: Their Users and Social Implications-A Longitudinal Study. J. Comput. Commun. 2012, 17, 467-488. [CrossRef]

22. Chang, T.-S.; Hsiao, W.-H. Time Spent on Social Networking Sites: Understanding User Behavior and Social Capital. Syst. Res. Behav. Sci. 2013, 31, 102-114. [CrossRef]

23. Boczkowski, P.J.; Matassi, M.; Mitchelstein, E. How Young Users Deal With Multiple Platforms: The Role of Meaning-Making in Social Media Repertoires. J. Comput. Commun. 2018, 23, 245-259. [CrossRef]

24. Hund, E.; McGuigan, L. A Shoppable Life: Performance, Selfhood, and Influence in the Social Media Storefront. Commun. Cult. Crit. 2019, 12, 18-35. [CrossRef]

25. Lee, E.-J.; Oh, S.Y. Seek and You Shall Find? How Need for Orientation Moderates Knowledge Gain from Twitter Use. J. Commun. 2013, 63, 745-765. [CrossRef]

26. Reinecke, L.; Vorderer, P.; Knop, K. Entertainment 2.0? The Role of Intrinsic and Extrinsic Need Satisfaction for the Enjoyment of Facebook Use. J. Commun. 2014, 64, 417-438. [CrossRef]

27. Ren, Q.; Xu, F.; Ji, X. Use of the pathfinder network scaling to measure online customer reviews: A theme park study. Strat. Chang. 2019, 28, 333-344. [CrossRef]

28. Fardous, J.; Du, J.T. Tourists' social interactions on social media during a group trip planning. Proc. Assoc. Inf. Sci. Technol. 2019, 56, 642-644. [CrossRef]

29. Yuan, C.; Tian, W. The Influences of Dual Social Network Site Use and Social Capital Development on Sociocultural Adaptation. Ph.D. Thesis, Cornell University, Ithaca, NY, USA, 2015.

30. Chari, S.; Christodoulides, G.; Presi, C.; Wenhold, J.; Casaletto, J.P.; Gonçalves, H.M.; Rey-Martí, A.; Roig-Tierno, N.; Miles, M.P. Consumer Trust in User-Generated Brand Recommendations on Facebook. Psychol. Mark. 2016, 33, 1071-1081. [CrossRef]

31. Park, M.-S.; Shin, J.-K.; Ju, Y. A Taxonomy of Social Networking Site Users: Social Surveillance and Self-surveillance Perspective. Psychol. Mark. 2015, 32, 601-610. [CrossRef]

32. Rydén, P.; Kottika, E.; Hossain, M.; Skare, V.; Morrison, A.M. Threat or treat for tourism organizations? The Copenhagen Zoo social media storm. Int. J. Tour. Res. 2019, 22, 108-119. [CrossRef]

33. Glińska, E.; Rudolf, W. City Brand Personality Projected by Municipalities from Central and Eastern Europe Countries-A Comparison of Facebook Usage. Sustainability 2019, 11, 5440. [CrossRef]

34. Kantanen, T. Analysis of the Contents of Theatre Visiting Orientation. In Proceedings of University of Vaasa; Research Paper; Business Administration: Vaasa, Finland, 1993.

35. Parsons, T.; Shills, E.A. Toward a General Theory of Action; Harper \& Row: New York, NY, USA, 1967.

36. Laurent, G.; Kapferer, J.-N. Les profils d'implication. Rech. Appl. Mark. 1986, 1, 41-57. [CrossRef]

37. Hirschman, E.C. Experience seeking: A subjectivist perspective of consumption. J. Bus. Res. 1984, 12, $115-136$. [CrossRef]

38. Laaksonen, M. Shopping Orientation: An Attitude Structure Approach. In Proceedings of University of Vaasa; Research Paper; Business Administration: Vaasa, Finland, 1987.

39. Wann, D.L. Preliminary Validation of the Sport Fan Motivation Scale. J. Sport Soc. Issues 1995, 19, 377-396. [CrossRef]

40. Swanson, S.R.; Larson, B.V.; Janda, S. Motivations of College Students Game Attendance and Word-of-Mouth Behavior: The Impact of Gender Differences. Sport Mark. Q. 2003, 12, 151-169.

41. Pons, F.; Mourali, M.; Nyeck, S. Consumer Orientation Toward Sporting Events. J. Serv. Res. 2006, 8, $276-287$. [CrossRef]

42. Zinkhan, G.M.; Muderrisoglu, A. Involvement, familiarity, cognitive differentiation, and advertising recall: A test of convergent and discriminant validity. Adv. Consum. Res. 1985, 12, 251-256.

43. Mowen, J.C. Consumer Behaviour, 4th ed.; Prentice-Hall: Englewood Cliffs, NJ, USA, 1995.

44. Alba, J.W.; Hutchinson, J.W. Dimensions of Consumer Expertise. J. Consum. Res. 1987, 13, 411. [CrossRef] 
45. Barbara, S.; Smith, T.R. A computational process of evaluation based on the cognitive structuring of episodic knowledge. Assoc. Consum. Res. 1982, 8, 136-143.

46. Wei, M.-L.; Fischer, E.; Main, K.J. An Examination of the Effects of Activating Persuasion Knowledge on Consumer Response to Brands Engaging in Covert Marketing. J. Public Policy Mark. 2008, 27, $34-44$. [CrossRef]

47. Ray, M.L.; Sawyer, A.G. Repetition in Media Models: A Laboratory Technique. J. Mark. Res. 1971, 8, $20-29$. [CrossRef]

48. Arora, R.; Stoner, C. The effect of perceived service quality and name familiarity on the service selection decision. J. Serv. Mark. 1996, 10, 22-34. [CrossRef]

49. Han, C.M.; Terpstra, V. Country-of-Origin Effects for Uni-National and Bi-National Products. J. Int. Bus. Stud. 1988, 19, 235-255. [CrossRef]

50. Biswas, A. The moderating role of brand familiarity in reference price perceptions. J. Bus. Res. 1992, 25, 251-262. [CrossRef]

51. Baloglu, S. Image variations of Turkey by familiarity index: Informational and experiential dimensions. Tour. Manag. 2001, 22, 127-133. [CrossRef]

52. Prentice, R.C. The distant familiar? Young british adults' imaginings of Australia. In Riding the Wave of Tourism and Hospitality Research; Braitwaite, R., Braithwaite, R., Eds.; Southern Cross University: Lismore, NSW, Australia, 2003.

53. Kent, R.; Allen, C. Competitive interference effects in consumer memory for advertising: The role of brand familiarity. J. Mark. 1994, 58, 97-105. [CrossRef]

(C) 2020 by the authors. Licensee MDPI, Basel, Switzerland. This article is an open access article distributed under the terms and conditions of the Creative Commons Attribution (CC BY) license (http://creativecommons.org/licenses/by/4.0/). 